WARSZTATY Z GEOGRAFII TURYZMU

ISBN 978-83-7969-138-8 $\quad$ s. 35-47

http://dx.doi.org/10.18778/7969-138-8.04

Krzysztof PARZYCH

Akademia Pomorska w Słupsku

\title{
PARKI TEMATYCZNE JAKO NOWA ATRAKCJA TURYSTYCZNA REGIONU NADMORSKIEGO: STUDIUM PRZYPADKU ŁEBY
}

Wybrzeże Morza Bałtyckiego stanowi główny obszar recepcyjny turystyki w Polsce. Wynika to z charakteru jego dominujących walorów predestynowanych do uprawiania klasycznej turystyki wypoczynkowej. Z obszarem tym związana jest też największa koncentracja zagospodarowania noclegowego na tle całego kraju (JAŻEWICZ, RYDZ 2008, JAŻEWICZ 2011, MIEDZIŃSKI 2011, SZWICHTENBERG 2006, PARZYCH 2009, 2011, PAWLICZ 2008).

Występujące na terenie wybrzeża Bałtyku walory turystyczne determinują jego wykorzystanie przede wszystkim przez masową turystykę wypoczynkową oraz na wybranych odcinkach wybrzeża przez turystykę uzdrowiskową, turystykę krajoznawczą i różne formy turystyki kwalifikowanej w oparciu o walory akwenu Morza Bałtyckiego.

Zmieniające się w skali świata uwarunkowania rozwoju turystyki związane $\mathrm{z}$ coraz szerszym uczestnictwem $\mathrm{w}$ ruchu turystycznym prowadzą do zmian w dotychczasowym jego charakterze. Tradycyjny typ turystyki określony symboliką 3S został zastąpiony współcześnie symboliką 3E (entertainment, experience, education), który wiąże się z istotnymi zmianami charakteru dotychczasowych form ruchu turystycznego.

Dynamiczny rozwój ruchu turystycznego i związany z nim rozwój zagospodarowania turystycznego objawiający się nie tylko ilościowym przyro- 
stem obiektów bazy noclegowej, ale również zmianami jej struktury, staje się motorem napędowym rozwoju ruchu turystycznego $\mathrm{w}$ miejscowościach nadmorskich. Inwestycje ilościowe i jakościowe w obiekty zagospodarowania noclegowego wywołują efekt przyciągania kolejnych inwestycji w zakresie bazy gastronomicznej, dostępności komunikacyjnej oraz różnych obiektów infrastruktury towarzyszącej.

Rozwój turystyki na polskim wybrzeżu Bałtyku nie dotyczy jednak tylko zagospodarowania turystycznego oraz usług paraturystycznych. Elementem współczesnego rozwoju turystyki są również próby kreowania nowych atrakcji turystycznych $\mathrm{w}$ miejscowościach nadmorskich. Nowe atrakcje turystyczne mogą stanowić dodatkowy element urozmaicenia turystycznych obszarów recepcyjnych. Ponadto poza sezonem mogą przyciągać turystów z najbliższego otoczenia kurortu, a w dłuższej perspektywie mogą stanowić również podstawę do wydłużenia sezonu turystycznego. Odgrywa to szczególną rolę w odniesieniu do tradycyjnych nadmorskich kurortów wypoczynkowych, których rozwój społeczno-ekonomiczny jest często uzależniony od ich funkcji recepcyjnej. Wiele $\mathrm{z}$ tych miejscowości, poszukując możliwości przyciągnięcia turystów także w okresie po sezonie urlopowo-wypoczynkowym, podejmuje próby kreowania nowych atrakcji turystycznych.

W niniejszym opracowaniu podjęto analizę roli, jaką odgrywają parki tematyczne w rozwoju ruchu turystycznego miejscowości nadmorskiej. W tym celu posłużono się studium przypadku Łeby - jednego z dominujących kurortów turystycznych w środkowej części Pobrzeża Bałtyku. W pierwszej części opracowania dokonano analizy atrakcyjności turystycznej parków tematycznych wybrzeża, ze szczególnym uwzględnieniem parków tematycznych Łeby. W drugiej części dokonano analizy wybranych cech ruchu turystycznego w nich na podstawie wyników przeprowadzonych badan terenowych.

Parki tematyczne odgrywają bardzo istotną rolę w rozwoju współczesnej turystyki (KRUCZEK 2012, PISARSKI 2010, PIEŃKOWSKI 2011). W zależności od skali organizacyjnej przedsięwzięcia, lokalizacji i tematyki mogą stanowić same w sobie destynację turystyczną przyciągając miliony turystów rocznie bądź być elementem uzupełniającym atrakcyjność turystyczną miejscowości o innym profilu realizowanej funkcji turystycznej. W skali świata parki tematyczne przyciągają olbrzymią liczbę odwiedzających. Ponadto z każdym rokiem odnotowuje się znaczny wzrost ich liczby. W roku 2011 parki tematyczne odwiedziło w skali świata 335,7 mln turystów, a w 2012 liczba ta wynosiła $357 \mathrm{mln}$ (Theme index 2012). 
Na duże zainteresowanie parkami rozrywki i tematycznymi wśród turystów wpływają następujące czynniki:

- wyjątkowość oferty, która jest skierowana do indywidualnych turystów lub do różnych grup odbiorców;

- innowacyjność, dążenie do rozwoju przestrzennego i zakresu oferowanych usług;

- interesująca tematyka;

- wykorzystanie zaawansowanej technologii w realizacji przedsięwzięcia;

- sprawny system zarządzania;

- wysoka jakość realizowanych usług wraz z wysokim poczuciem bezpieczeństwa odwiedzających;

- odpowiednio wyszkolony personel.

Ponadto parki tematyczne odgrywają istotną rolę dla lokalnych rynków pracy, zwłaszcza tam, gdzie mamy do czynienia z wysokim stopniem sezonowości ruchu turystycznego, a poza tym w ostatnich latach mają coraz większe znaczenie $\mathrm{w}$ rozwoju turystycznym gmin nadmorskich polskiego wybrzeża.

Obiekty te z reguły są zlokalizowane w bezpośrednim sąsiedztwie plaży nadmorskiej, w obrębie pasa leśnego stanowiącego strefę buforową dla plaży nadmorskiej, w centralnej handlowo-usługowej części miejscowości lub w naturalnym, $\mathrm{z}$ reguły zalesionym krajobrazie peryferyjnej, południowej części miejscowości nadmorskich. Ze względu na typ parku połowa z ponad 20 parków tematycznych wśród funkcjonujących $\mathrm{w}$ regionie nadmorskim to parki linowe (11). Ponadto istnieją $\mathrm{w}$ tej grupie parki miniatur, parki nawiązujące tematyką do lokalizacji na obszarze nadmorskim, a także parki dinozaurów w Łebie oraz w miejscowości Dargobądz na Wyspie Wolin (tab. 1).

Parki tematyczne funkcjonujące na terenach nadmorskich są obiektami bardzo młodymi. Obecnie są raczej niewielkie i charakteryzują się znacznie mniejszymi przedsięwzięciami logistycznymi w porównaniu z największymi tego typu obiektami w Europie i na świecie.

Dość szczególną miejscowością ze względu na lokalizacje parków tematycznych w grupie miejscowości nadmorskich jest Łeba, w której funkcjonują cztery tego typu obiekty, a w jej bezpośrednim sąsiedztwie jeszcze jeden, jakim jest Sea Park w Sarbsku. Łeba jest jedną z najpopularniejszych miejscowości nadmorskich, położonych na środkowym wybrzeżu Bałtyku. Położona pomiędzy jeziorami Łebsko i Sarbsko, przy ujściu rzeki Łeby do Bałtyku, zamieszkiwana jest przez przeszło 3753 osoby (stan na rok 2012 r.). Dominu- 
jące walory turystyczne Łeby wiążą się z jej walorami wypoczynkowymi oraz krajoznawczymi. Łeba jako miejscowość recepcyjna turystyki jest przede wszystkim postrzegana przez pryzmat swoich walorów wypoczynkowych wynikających $\mathrm{z}$ nadmorskiego położenia, któremu towarzyszą dogodne warunki pogodowe $\mathrm{z}$ długim sezonem kąpielowym, oraz wysokie wskaźniki usłonecznienia w sezonie urlopowo-wakacyjnym. Ponadto Łeba posiada najbogatsze zasoby bazy noclegowej wśród innych miejscowości wypoczynkowych polskiego wybrzeża Bałtyku, które według danych oficjalnych wynosiły w 2012 r. około 8500 miejsc noclegowych (Bank Danych Lokalnych GUS). Badania terenowe oraz kwerenda witryn internetowych pozwala szacować rzeczywistą skalę zagospodarowania noclegowego Łeby na około 19000 miejsc noclegowych. Według oficjalnych statystyk GUS, Łeba jest odwiedzana przez około 84046 turystów, chociaż dane te z pewnością nie odzwierciedlają pełnej skali ruchu turystycznego w kurorcie.

Tabela 1. Parki tematyczne zlokalizowane na obszarze gmin nadmorskich w Polsce

\begin{tabular}{|l|c|c|c|}
\hline \multicolumn{1}{|c|}{ Park tematyczny } & $\begin{array}{c}\text { Rok } \\
\text { powstania }\end{array}$ & Lokalizacja & $\begin{array}{c}\text { Powierzchnia } \\
\text { w ha }\end{array}$ \\
\hline Bałtycki Park Dinozaurów & 2012 & Kamień Pomorski & 10,0 \\
\hline Dino Park & 2012 & \multicolumn{2}{|c|}{ Góra Chełmska } \\
\hline Power Park Łeba & 2010 & Łeba & 10,0 \\
\hline Tarzan Park Łeba & 2010 & Łeba & 10,0 \\
\hline Łeba Park & 2010 & Łeba & 20,0 \\
\hline Oceanarium & 2010 & Łeba & \\
\hline Nadmorski Park Miniatur & 2012 & Dziwnów & 5,0 \\
\hline Park Miniatur Latarni Morskich & 2012 & Niechorze & 5,0 \\
\hline Luna Park & 2012 & Krynica Morska & 5,0 \\
\hline Sea Park & 2012 & Sarbsk & 10,0 \\
\hline Park Linowy Linowo & 2012 & Dębki & 1,5 \\
\hline Park Linowy Małpi Jar & 2008 & Gdańsk Oliwa & 1,5 \\
\hline Park Linowy Góra Harców & 2010 & Gdynia & 1,5 \\
\hline Park Linowy Ju huu & 2012 & Jurata & 1,5 \\
\hline Park Linowy & 2011 & Krynica Morska & 1,5 \\
\hline Park Linowy Extreme & 2012 & Rowy & 1,5 \\
\hline Park Linowy & 2008 & Stegna & 1,5 \\
\hline Park Linowy & 2010 & Dolina Charlotty & 1,5 \\
\hline Park Linowy na Wydmie & 2010 & Ustka & 1,5 \\
\hline Tarzan Park Władysławowo & 2010 & Władysławowo & 1,5 \\
\hline Woliński Park Dinoazaurów & 2010 & Dargobądz & 10,0 \\
\hline
\end{tabular}

Źródło: opracowanie własne. 
Ważną atrakcją turystyczną Łeby obok jej walorów wypoczynkowych jest jej położenie w sąsiedztwie Słowińskiego Parku Narodowego z największym $\mathrm{w}$ Polsce kompleksem wydm nadmorskich oraz $\mathrm{z}$ dużymi jeziorami przybrzeżno-polodowcowymi i związanym z nimi bogactwem ornitofauny. Ponadto na atrakcyjność turystyczną Łeby i jej okolic składają się walory antropogeniczne, przede wszystkim pozostałości kultury materialnej Słowińców głównie w Skansenie Wsi Słowińskiej w Klukach oraz budownictwo szachulcowe okolicznych miejscowości Izbica, Gać, Kluki. Bogactwo walorów turystycznych stało się podstawą rozwoju infrastruktury turystycznej w kurorcie. Rozwój zagospodarowania turystycznego przybrał na sile zwłaszcza od lat 90. XX w. Oprócz bazy noclegowej w ostatnich latach w Łebie powstało wiele obiektów infrastruktury towarzyszącej. Istotnymi nowymi elementami atrakcyjności turystycznej Łeby, które rozwinęły się w ostatnich latach stały się nowo powstające parki tematyczne.

Parki tematyczne i inne atrakcje turystyczne Łeby są rozmieszczone nieregularnie w przestrzeni miasta. Parki tematyczne Łeby obejmują następujące obiekty: Łeba Park - Park Dinozaurów, który zlokalizowany jest na południowym wschodzie Łeby, Muzeum Motyli Świata znajdujące się w ścisłym centrum Łeby, Ogród Ornitologiczny w Nowęcinie oraz Oceanarium, które znajduje się w centrum Łeby przy ulicy Kościuszki.

Wśród parków rozrywki znajdujących się w Łebie można wyróżnić: Power Park Łeba zlokalizowany przy ulicy Nadmorskiej, Tarzan Park Łeba park linowy, który mieści się przy ulicy Turystycznej, w kierunku na Rąbkę, oraz Lunapark Krasnal Łeba przy ulicy Wspólnej. Warto wspomnieć, że w latach 2001 i 2008 w kurorcie funkcjonowało Western City. Miasteczko zlokalizowane było przy ulicy Nadmorskiej 4d. Miejsce to skupiało się na kreowaniu kultury rodem z Dzikiego Zachodu. Obiekt został zamknięty z braku zainteresowania kulturą Dzikiego Zachodu przez turystów.

Największym parkiem tematycznym Łeby jest Łeba Park - Park Dinozaurów, zlokalizowany w południowej części miasta, na obszarze silnie podmokłym, który stwarza dogodne warunki krajobrazowe doskonale komponujące się $\mathrm{z}$ tematyką parku. Prace nad utworzeniem parku rozpoczęto w 2008 r. i trwały do 2010 r., kiedy 29 maja udostępniono park odwiedzającym. Obszar parku obejmuje 20 ha terenu pokrytego typową roślinnością bagienno-torfowiskową. Znajduje się $\mathrm{w}$ nim przeszło 100 figur naturalnej wielkości prehistorycznych gadów (z największych - jeden ma $13 \mathrm{~m}$ wysokości, a drugi $45 \mathrm{~m}$ długości) oraz inne prehistoryczne gatunki zwierząt oraz osady neandertalczyków. W parku poza eksponatami dinozaurów znajdują 
się niewielkie zoo, plac zabaw, kino, punkty handlowe i wiele innych atrakcji (rys. 1).

Specyficzną formą parku tematycznego może być Muzeum Motyli Świata w Łebie, w którym przedmiotem kolekcji jest 6000 spreparowanych okazów motyli i innych owadów umieszczonych w 102 gablotach. Obiekt

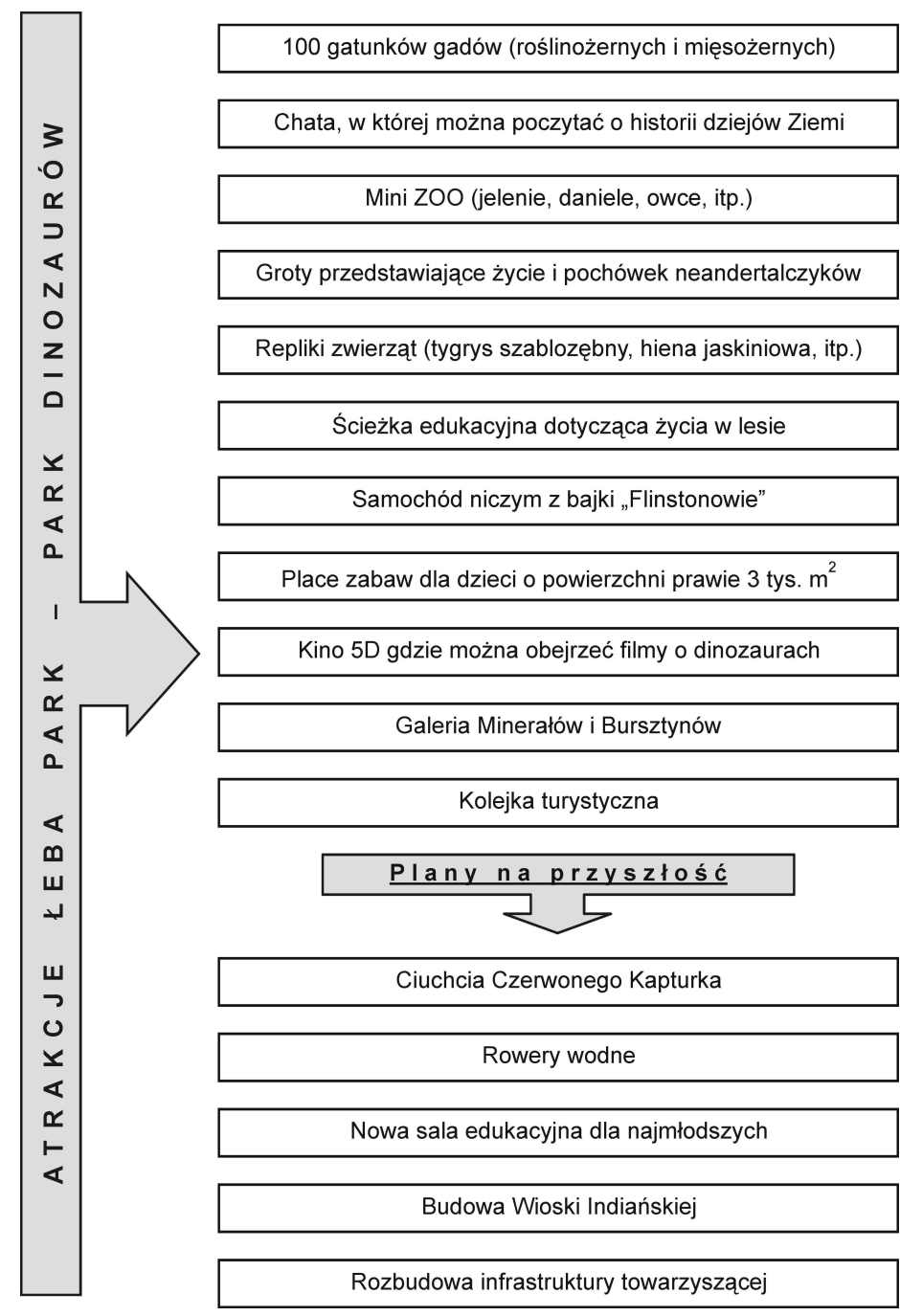

Rys. 1. Schemat atrakcji Łeba Park - Park Dinozaurów

Źródło: D. SZAJNER (2010) 
udostępniono odwiedzającym w 1998 r. Elementem zainteresowania odwiedzających jest ponadto bogata kolekcja znaczków z motylami. Największe wrażenie na odwiedzających wywołują jednak preparaty motyli z metkami odręcznie pisanymi piórem z 1906 czy 1914 r.

Interesującym parkiem tematycznym jest park - Ogród Ornitologiczny, który został utworzony w 2000 r. na terenie Jeziora Mielnickiego. Początkowo obejmował obszar 6 ha, obecnie zajmuje powierzchnię 20 ha w peryferyjnej południowo-wschodniej części miasta w sąsiedztwie Łeba Parku. W parku znajduje się około 200 gatunków ptaków umieszczonych w specjalnie przygotowanych wolierach. Jego pomysłodawcą i zarazem właścicielem jest miejscowy pasjonat i ornitolog, który interesuje się ptakami od przeszło 50 lat.

Kolejnym parkiem tematycznym Łeby jest Oceanarium. Obiekt ten zlokalizowany jest w centralnej części Łeby. Stwarza możliwość podziwiania kolekcji ryb przede wszystkim strefy raf koralowych (zebrasomy, ukwiały symbiotyczne, rodzina amfiprionów, hepatus). Ponadto znajdują się tu: rekiny, arapaima, drapieżne barrakudy i mureny, kraby mangrowe, skrzydlica pstra, najeżnik i wiele innych gatunków ryb z różnych zakątków świata. Obiekt funkcjonuje wyłącznie w sezonie letnim.

Poza wymienionymi w granicach Łeby funkcjonują dwa parki tematyczne - parki rozrywki: Power Park oraz Tarzan Park. Power Park Łeba mieści się w północno-wschodniej części Łeby w bliskim sąsiedztwie plaży nadmorskiej. Power Park, położony na obrzeżach Łeby, przyciąga wieloma atrakcjami, m.in. torem gokartowym, torem off-road, strzelnicą, skokiem wahadłowym, polem do gry w paintball. Park zlokalizowany jest w urozmaiconym krajobrazie (las, łaka, piasek wydmowy) na obszarze 2 ha. Park funkcjonuje w okresie od maja do końca września.

Tarzan Park Łeba to typowy park linowy; usytuowany w zachodniej części Łeby. Wytyczono w nim cztery trasy z 62 przeszkodami (tyrolka, liny, drabinki, platformy, mostki itp.) o łącznej długości $666 \mathrm{~m} \mathrm{w}$ powietrzu, przy maksymalnej wysokości 9-10 m. Kompleks jest oświetlony, co stwarza możliwość korzystania z niego również w godzinach wieczornych.

W celu oceny funkcjonowania parków tematycznych i ich atrakcyjności turystycznej w opinii odwiedzających dokonano badan ankietowych na populacji 400 turystów odwiedzających Łebę. Ponadto, aby ocenić zasięg oddziaływania turystycznego, wykonano pomiary ruchu samochodowego na parkingu w pobliżu Łeba Parku oraz Parku Ornitologicznego. Badania miały na celu określenie zasięgu oddziaływania parków tematycznych Łeby oraz 
percepcji przestrzeni turystycznej parków i wybranych cech ruchu turystycznego w parkach tematycznych Łeby. Ogółem 400 osób uczestniczących w prowadzonym badaniu wskazało 1126 odwiedzin w sześciu parkach tematycznych Łeby. Z tego najwięcej, bo 254 wizyt, dotyczyło Muzeum Motyli Świata, 204 Power Parku, a 180 Łeba Parku (rys. 2).
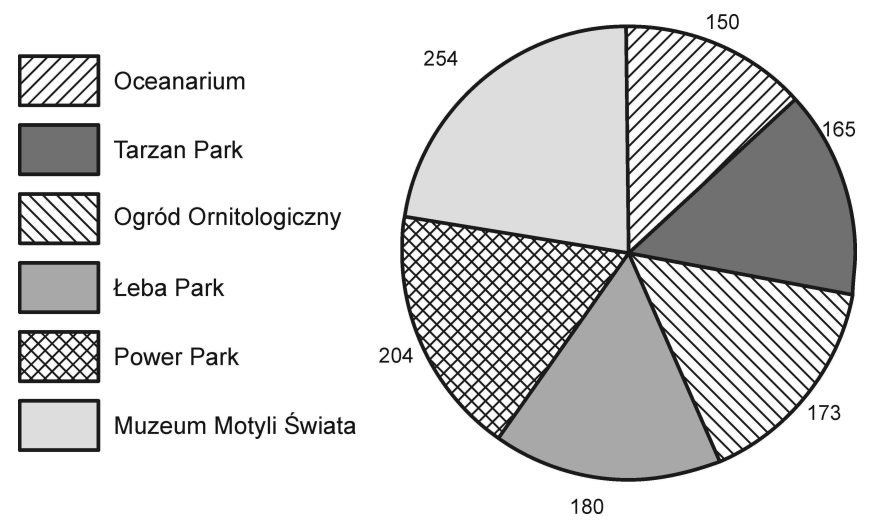

Rys. 2. Wykaz atrakcji odwiedzonych przez ankietowanych podczas pobytu w Łebie Źródło: opracowanie własne na podstawie badań ankietowych

Analizy zasięgu oddziaływania parków tematycznych Łeby dokonano $\mathrm{w}$ oparciu o pochodzenie respondentów uczestniczących $\mathrm{w}$ badaniu ankietowym oraz na podstawie oznaczeń tablic rejestracyjnych samochodów osobowych parkujących w dniu 10.07.2011 na parkingu w Pobliżu Łeba Parku oraz Parku Ornitologicznego (tab. 2).

Aby ocenić pochodzenie terytorialne turystów odwiedzających Łeba Park oraz Park Ornitologiczny w Łebie dokonano pomiarów ilościowych samochodów na parkingu zlokalizowanym w sąsiedztwie parków, jak również miejsca (województwa) ich rejestracji. Pomiar ten odbył się 26 lipca 2011 r. o godzinie $14^{00}$. Podczas trwania tego spisu zostało zarejestrowanych 201 samochodów osobowych z 14 województw Polski; nie zarejestrowano samochodów z województw lubuskiego i opolskiego. Na parkingu były też cztery busy z województwa pomorskiego oraz pięć autokarów (po jednym z podkarpackiego, wielkopolskiego, zachodniopomorskiego i dwa z pomorskiego). Największą w badanej liczbie pojazdów grupę samochodów odnotowano z województwa pomorskiego - przeszło 40,8\%, w dalszej kolejności z mazowieckiego (20,9\%). Pozostałe województwa mają niewielki udział procentowy, bo zaledwie od 0,5\% kujawsko-pomorskie do 6,47\% śląskie. 
Tabela 2. Pochodzenie terytorialne samochodów osobowych zarejestrowanych w trakcie obserwacji na parkingu Łeba Park - Park Dinozaurów 26 lipca 2011 r.

\begin{tabular}{|l|c|c|}
\hline \multicolumn{1}{|c|}{ Województwo } & $\begin{array}{c}\text { Liczba samochodów } \\
\text { osobowych }\end{array}$ & Odsetek \\
\hline Dolnośląskie & 7 & 3,48 \\
\hline Kujawsko-pomorskie & 1 & 0,50 \\
\hline Lubuskie & 0 & 0,00 \\
\hline Lubelskie & 6 & 2,99 \\
\hline Łódzkie & 9 & 4,48 \\
\hline Małopolskie & 9 & 4,48 \\
\hline Mazowieckie & 42 & 20,90 \\
\hline Opolskie & 0 & 0,00 \\
\hline Podkarpackie & 4 & 1,99 \\
\hline Podlaskie & 2 & 1,00 \\
\hline Pomorskie & 82 & 40,80 \\
\hline Śląskie & 13 & 6,47 \\
\hline Świętokrzyskie & 2 & 1,00 \\
\hline Warmińsko-mazurskie & 10 & 4,98 \\
\hline Wielkopolskie & 5 & 2,49 \\
\hline Zachodniopomorskie & 9 & 4,48 \\
\hline Razem: & 201 & 100,00 \\
\hline
\end{tabular}

Źródło: D. SZAJNER (2010).

Częściowej informacji o pochodzeniu turystów dostarczyły również dane z metryczki badania ankietowego przeprowadzonego na populacji 400 odwiedzających łebskie parki tematyczne.

Turyści respondenci odwiedzający parki tematyczne Łeby pochodzili przede wszystkim z województwa pomorskiego (103 osoby - ponad 26\% ogółu badanych), ponadto znacząca liczba odwiedzających pochodziła z województwa zachodniopomorskiego (54 osoby) i z mazowieckiego (41 osób). Najmniejsze grupy turystów wśród badanych odwiedzających łebskie parki tematyczne odnotowano z województw śląskiego (8) i świętokrzyskiego (9).

Ponadto w czasie pomiaru stwierdzono obecność 14 samochodów z rejestracją zagraniczną (Niemcy, Norwegia, Dania, Wielka Brytania). Wynika z tego, że aż 93\% pojazdów na badanym parkingu to pojazdy krajowe, a zaledwie $7 \%$ zagraniczne (rys. 2).

Dokonano analizy źródeł informacji o parkach wśród badanej populacji odwiedzających. Najwięcej osób (198 - 28,3\% ogółu) uzyskało informacje o odwiedzanych parkach za pośrednictwem Internetu, ale cennymi źródłami o ofercie parków tematycznych Łeby były foldery (174 osoby), informacje 
uzyskane od znajomych (169 osób) oraz ze środków masowego przekazu (radio, telewizja - 154 osoby).

Parki tematyczne Łeby są - jak wspomniano na początku - w większości obiektami bardzo młodymi, zatem większość badanych turystów odwiedzała je po raz pierwszy. Najczęściej odwiedzanym w przeszłości spośród wszystkich parków tematycznych Łeby był Łeba Park - Park Dinozaurów, w którym w trakcie ubiegłych podróży było 130 spośród 400 badanych turystów $(32,50 \%$ ogółu badanej populacji).

Łebskie parki tematyczne charakteryzują się dużą atrakcyjnością turystyczną, co jest efektem ich lokalizacji w popularnym kurorcie nadmorskim oraz bogatej oferty atrakcji turystycznych przygotowanych z myślą o odwiedzających. W celu dokonania oceny poszczególnych elementów atrakcyjności turystycznej parków tematycznych Łeby respondentów poproszono o przypisanie oceny poszczególnym elementom atrakcyjności turystycznej parków w skali od 1 do 5 (tab. 3). Najlepiej w badanej grupie oceniano walory poznawcze oraz organizację i obsługe parku. Najniższe noty uzyskała lokalizacja parku, tj. jego położenie w przestrzeni miasta. Może to oznaczać, że dla turystów mniejsze znaczenie miały walory lokalizacyjne parku w interesującej pod względem przyrodniczym okolicy, większą rolę odgrywała natomiast jego dostępność, prawdopodobnie oddalenie od plaży. Najatrakcyjniejsze parki tematyczne Łeby są zlokalizowane na peryferyjnych obszarach miasta.

Tabela 3. Ocena poszczególnych elementów atrakcyjności turystycznej parków tematycznych w Łebie dokonana przez turystów je odwiedzających

\begin{tabular}{|l|r|r|r|r|r|}
\hline Elementy atrakcyjności & \multicolumn{5}{|c|}{ Ocena } \\
\cline { 2 - 6 } turystycznej w parkach & 1 & 2 & 3 & 4 & 5 \\
\hline Walory poznawcze & 32 & 20 & 134 & 82 & 132 \\
\hline Infrastruktura & 0 & 86 & 185 & 83 & 46 \\
\hline Obsługa i organizacja & 5 & 78 & 66 & 188 & 63 \\
\hline Położenie parku & 11 & 60 & 228 & 94 & 7 \\
\hline
\end{tabular}

Źródło: D. SZAJNER (2010).

Turyści, poproszeni o wskazanie motywów wizyty w Łeba Parku - Park Dinozaurów, najczęściej wskazywali jego walory wypoczynkowe, rekreacyjne (tab. 4), podkreślając, że jest to miejsce, w którym można bardzo sympatycznie spędzić czas w gronie rodziny lub znajomych (33,3\% badanych). Częstymi motywami odwiedzin dla znaczącej liczby respondentów były 
ponadto pozytywne wrażenia, wspomnienia wyniesione $\mathrm{z}$ poprzednich wizyt w parku (22,2\% respondentów) oraz walory poznawcze parku ( $22 \%$ odpowiedzi).

Tabela 4. Motywy odwiedzin Łeba Parku - Parku Dinozaurów przez badaną populację turystów

\begin{tabular}{|l|r|r|}
\hline \multicolumn{1}{c|}{$\begin{array}{c}\text { Motyw kolejnych odwiedzin parków } \\
\text { tematycznych Łeby i jej okolic }\end{array}$} & \multicolumn{2}{c|}{ Wskazania } \\
\cline { 2 - 3 } & liczba & odsetek \\
\hline Walory poznawcze parku & 149 & 22,0 \\
\hline Walory wypoczynkowe parku & 226 & 33,3 \\
\hline Bogata oferta różnorodnych atrakcji & 94 & 13,8 \\
\hline Profesjonalna obsługa & 44 & 6,5 \\
\hline Pozytywne wrażenia z poprzednich wizyt & 151 & 22,2 \\
\hline Brak odpowiedzi & 15 & 2,2 \\
\hline Razem & 679 & 100,0 \\
\hline
\end{tabular}

Źródło: D. SZAJNER (2010).

Należy podkreślić, że większość respondentów, którzy odwiedzali parki tematyczne Łeby była już w przeszłości w innych parkach tematycznych. W badanej grupie blisko $46 \%$ osób zadeklarowało wcześniejsze odwiedziny w innym parku tematycznym. Najwięcej turystów wskazywało na wcześniejsze wizyty w parkach tematycznych w Karłowie, Kowarach i Mrągowie (tab. 5). Około $26 \%$ zadeklarowało, że nigdy wcześniej nie było w żadnym parku tematycznym, a aż $28 \%$ ankietowanych nie przypomina sobie wcześniejszej wizyty w tego typu obiekcie.

Tabela 5. Liczba dotychczasowych wizyt w innych parkach tematycznych wśród badanej populacji turystów odwiedzających łebskie parki tematyczne

\begin{tabular}{|l|r|c|}
\hline \multirow{2}{*}{$\begin{array}{c}\text { Odpowiedzi na pytanie o parki } \\
\text { tematyczne odwiedzane w przeszłości }\end{array}$} & \multicolumn{2}{|c|}{ Wskazania } \\
\cline { 2 - 3 } & liczba & odsetek \\
\hline Tak & 187 & 46,7 \\
\hline Karłów & 38 & 9,5 \\
\hline Rybnik & 21 & 5,2 \\
\hline Kowary & 37 & 9,2 \\
\hline Rabka Zdrój & 26 & 6,5 \\
\hline Karpacz & 29 & 7,2 \\
\hline Mrągowo & 36 & 9,0 \\
\hline Nie & 102 & 25,5 \\
\hline Nie pamiętam & 111 & 27,7 \\
\hline Razem: & 400 & 100,0 \\
\hline
\end{tabular}

Źródło: D. SZAJNER (2010). 
W analizie percepcji przestrzeni turystycznej łebskich parków tematycznych odwiedzających zapytano o sugestie dotyczące zmian $\mathrm{w}$ organizacji przestrzeni parków w celu zwiększenia ich atrakcyjności turystycznej. W badanej grupie 98 osób (blisko 25\% badanej populacji) nie udzieliło odpowiedzi na to pytanie. Spośród tych, którzy odpowiedzieli na zadane pytanie 78 osób $(19,5 \%)$ podkreślało konieczność poprawy marketingu i reklamy parków. Ponadto 66 osób (16,5\%) wskazało na zwiększenie liczby atrakcji w parkach rozrywki, a 64 osoby (16\%) podkreśliło konieczność udostępnienia oferty odwiedzającym przez cały rok.
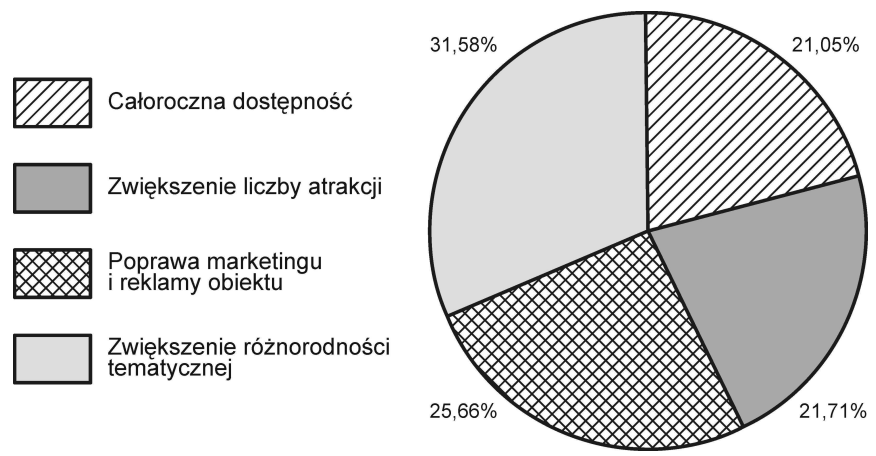

Rys. 3. Propozycje zmian w parkach tematycznych Łeby w celu zwiększenia ich atrakcyjności turystycznej w opinii respondentów

Źródło: D. SZAJNER (2010)

Parki tematyczne oraz inne parki rozrywki stanowią w ostatnich latach jedno z najdynamiczniej rozwijających się zjawisk w światowej turystyce. Ich duża siła przyciągania turystycznego wynika z łączenia jednocześnie w sobie elementu dobrej zabawy, rozrywki, aktywności fizycznej i towarzyszącej jej niejednokrotnie rywalizacji oraz szeroko pojmowanych elementów edukacyjnych. Pojawienie się parków tematycznych w miejscowościach nadmorskich i ich dynamiczny rozwój w ostatnich latach wynika z jednej strony z rosnących wymagań turystów przyjeżdżających na wybrzeże, poszukujących czegoś więcej niż bierny wypoczynek na plaży połączony z kąpielami morskimi. $Z$ drugiej jednak strony miejscowości nadmorskie dla inwestorów to źródło olbrzymich mas turystów spragnionych wrażeń, atrakcji, nowych doświadczeń. Budowa parków rozrywki czy parków tematycznych w miejscowościach nadmorskich jest więc przedsięwzięciem bardzo korzystnym z punktu widzenia prywatnych inwestorów. W Łebie i w jej najbliższych 
okolicach w ostatnich 10 latach powstało sześć obiektów o charakterze parku rozrywki lub parku tematycznego. Analiza ich percepcji przez turystów je odwiedzających potwierdza duże zainteresowanie nowymi atrakcjami turystycznymi w tradycyjnych nadmorskich miejscowościach wypoczynkowych.

\section{LITERATURA}

JAŻEWICZ I., RYDZ E., 2001, Turystyka, jako czynnik rozwoju społeczno-ekonomicznego Łeby, Zeszyty Naukowe Wydziału Ekonomii i Zarządzania Politechniki Koszalińskiej, 8, Koszalin.

JAŻEWICZ I., 2011, Strategiczna rola turystyki w rozwoju Łeby, [w:] Funkcja turystyczna miasta, I. Jażdżewska (red.), XXI Konserwatorium Wiedzy o Mieście, Wyd. Uniwersytetu Łódzkiego, Łódź.

KRUCZEK Z., 2012, Parki tematyczne, jako flagowe atrakcje turystyczne. Rozwój i globalizacja, www. turystykakulturowa.org; 15.10.2013.

MIEDZINSSKI M., 2011, Kotobrzeg jako centrum turystyki uzdrowiskowo-wypoczynkowej po 20 latach przemian ustrojowych (1989-2009), [w:] Turystyka polska w latach 1989-2009, "Warsztaty z Geografii Turyzmu", t. 1, B. Włodarczyk, B. Krakowiak, J. Latosińska (red.), Wyd. Uniwersytetu Łódzkiego, Łódź, s. 115-126.

PARZYCH K., 2009, Postrzeganie kurortu nadmorskiego przez turystów na przyktadzie Łeby, „Problemy Ekologii Krajobrazu", XXV, s. 139-145.

PARZYCH K., 2011, The analysis of the tourist movement and tourist attractiveness of Dartowo resort in tourist opinion, "Journal of Ecology and Protection of the Coastline. Baltic Coastal Zone", 15 , s. 25-36.

PaWlicZ A., 2008, Promocja produktu turystycznego: turystyka miejska, Centrum Doradztwa i Informacji, Difin, Warszawa.

PIEŃKOWSKI G., 2011, Geologiczne muzea i parki tematyczne dźwignia edukacji, rozwoju i biznesu, „Przegląd Geologiczny", 59, 4.

PISARSKI M., 2010, Światowy przemyst parków tematycznych, http://atrakcje-marekpisarski.pl/ historia-branzy/swiatowy-przemysl-parkow-tematycznych-wedlug-marka-pisarskiego/.

RYDZ E., 2011, Rola turystyki w rozwoju strefy nadmorskiej na przykładzie Pomorza Środkowego, [w:] Turystyka. Księga jubileuszowa w 70. rocznice urodzin Profesora Stanistawa Liszewskiego, B. Włodarczyk (red.), Wyd. Uniwersytetu Łódzkiego, Łódź, s. 319-336.

SZAJNER D., 2010, Parki tematyczne Łeby, mpis pracy magisterskiej w Instytucie Geografii Akademii Pomorskiej w Słupsku.

SzWIChTENBERG A., 2006, Gospodarka turystyczna polskiego wybrzeża, Politechnika Koszalińska, Koszalin.

www.stat.gov.pl; 15.10.2013. 